„Tehetség, szorgalom, hivatás”

\author{
Tanulmánykötet
}

Kézirat lezárva: 2021. június 25. 
Kiadja:

a Magyar Rendészettudományi Társaság

Vám- és Pénzügyőri Tagozata

Szerkesztette:

Csaba Zágon és

Zsámbokiné Ficskovszky Ágnes

Felelős kiadó:

Szabó Andrea

ISBN: 978-615-81879-0-9

A mú szerzői jogilag védett. Minden jog, így különösen a sokszorosítás, terjesztés és fordítás joga fenntartva. A mű a kiadó írásbeli hozzájárulása nélkül részeiben sem reprodukálható, elektronikus rendszerek felhasználásával nem dolgozható fel, azokban nem tárolható, azokkal nem sokszorosítható és nem terjeszthetô. 
Szerzők

Lektorok

Lectori Salutem!

Tanulmányok

Christián László - Lippai Zsolt: Kakukktojás vagy új rendészeti alappillér?

Gonda Éva: Az Europol hospitáció hasznosítása a pénzügyi nyomozók képzése terén

Kakócz Krisztián - Vedó Attila: A toloncolás szabály- és szervezetrendszere a második világháború előtt

Kovács Gábor: A vezetői kompetenciák fejlesztésének lehetőségei a Rendészettudományi Kar hallgatóinak körében

Magasvári Adrienn: Egy új jogviszony „születése” - az adó- és vámhatósági szolgálati jogviszony vizsgálata ..

Molnár Katalin: Mi harminc? Tudománymetria helyett - Szerzőtársas játék................................ 87

Nyeste Péter: A modern bűnügyi hírszerzés modelljeinek fejlődése ............................................ 103

Pajor Andrea: Adóigazgatási tisztviselők képzése .

Sallai János - Borszéki Judit: Egy megvalósítható utópia? Közös munkanyelv keresése a nemzetközi rendőri együttmúködés kezdetén.

Suba László: Nyelvhelyesség a közszférában: Létkérdés vagy úri huncutság?

Szabó Andrea - Hájer Tamara: A vámfelsőoktatás uniós elismerési eljárásának elemei

Szlifka Gábor: Okos adózás, okos adóigazgatás - Minden ami okos, de mit is jelent pontosan?

Kutatási eredmények

Balla József - Kiss Lajos: A rendvédelmi szervező szakirányú továbbképzési szak indításának legfontosabb tapasztalatai.

Borzán Anita - Szekeres Bernadett: A digitalizáció hatása a gazdasági szakismeretek és a számvitel oktatására.

Duchon Jenő: Tanulási stílus és játékos típus összevetése felnőtteknél, az oktatási folyamat játékosítása céljából

Erdős Ákos - Somogyi Ágnes: Koffeinhasználat és koffeinhasználati zavar vizsgálata rendészeti hallgatók körében

Halasi Nóra: Feltáró kutatás a hivatástudat és motiváció jelentőségének vizsgálatára, a Hajdú-

Bihar Megyei Adó- és Vámigazgatóság személyi állományának összefüggésében 251 
DOI: $10.37372 / \mathrm{mrttvpt} .2021 .1 .12$

\title{
Szlifka Gábor*: Okos adózás, okos adóigazgatás - Minden ami okos, de mit is jelent pontosan?
}

\begin{abstract}
Absztrakt
Az 'okos' jelző korunk divatos kifejezése, amelynek egyértelműen innovatív tartalmat kölcsönöz a köznyelv. Az okos adózás és okos adóigazgatás nem jogi terminus technicusok, ugyanakkor egyre gyakrabban előforduló kifejezések. Éppen ezért célul tűztem ki annak vizsgálatát, hogy pontosan mit értünk ezen újonnan használatba került fogalmak alatt, lehete adójogi definíciót adni azoknak és azt milyen tartalommal. Igyekeztem elzárkózni az olyan tökéletes adójogi állapotot tükröző szóösszetételektől, mint okos adórendszer és okos adónem, bár az okos adóigazgatás kifejezés is egy minden szempontból optimális, kizárólag modernizált metódusokkal dolgozó adminisztrációt feltételez. Kísérletet teszek a fogalom lehetséges tartalmát az adózás modernizációjának irányaira és a joggyakorlatokban eddig megjelent megoldásokra alapozva meghatározni. Tanulmányomban áttekintem azokat a megvalósult vagy még átgondolás alatt lévő technikai-adójogi megoldásokat, amelyek egy vagy több ismérvük alapján e fogalom körébe sorolhatók. Nem törekszem a teljeskörűségre, azokat az új lehetőségeket és ötleteket vetem fel, amelyek a jelenkori adójogi gondolkodás és a nemzetközi adójogi gyakorlat fókuszában vannak, mindemellett besorolhatók az okos adózás mint fogalom szélesebb értelemben vett értelmezési tartományába.
\end{abstract}

Kulcsszavak: okos adózás, modernizáció, versenyképesség

\begin{abstract}
The word 'smart' is a fashionable phrase of our time, to which colloquial usage lends some clearly innovative connotations. 'Smart taxation' and 'smart tax administration' are not yet legal term but are increasingly common terms. That is why I aimed to examine exactly what we mean by these newly coined concepts, whether they can be given a tax law definition and what that would be. I tried to stay away from word combinations that reflect a perfect tax law scenario as 'smart tax system' and a 'smart tax type', although the term 'smart tax administration' also presupposes a tax administration that is optimal in all respects and works exclusively with modernized methods. I attempt to define the potential meaning of the concept based on the directions of modernization of current taxation and on the solutions that have appeared in case law so far. In my paper I review the technical/tax law solutions that have already been implemented or are being considered, and that can be included in this concept based on one or more criteria. I am not striving for completeness, I merely raise new possibilities and ideas that are the focus of contemporary tax law thinking and international tax law practice and that can be classified under the broader interpretation of smart taxation as a concept.
\end{abstract}

Keywords: smart taxation, modernisation, competitiveness

\footnotetext{
* Szlifka Gábor, Dr., PhD., ellenőrzési igazgatóhelyettes, NAV Pest Megyei AVIG, https://orcid.org/0000-
} 0003-2705-0350, szlifka.gabor@,nav.gov.hu 


\section{Okos adózás, mint fogalom}

Az okos megoldások és eszközök korát éljük, szinte nincs olyan szférája mindennapi életünknek, amelybe valamilyen okos eszköz, szoftver vagy módszer ne lenne jelen. Az okos vagy 'smart' kifejezés nyelvtanilag is divatszó lett, sőt új árnyalatban jelenít meg eddig létező fogalmakat, intézményeket. Az okos kifejezés, mint jelző mindenképpen egy pozitív változásra utal egy megelőző állapottal szemben, amely gyorsabb, költséghatékonyabb és kényelmesebb megoldást rejthet magában. Teljesen nyilvánvaló, hogy ez az új társadalmi, technikai és nyelvtani jelenség a digitalizációval van összefüggésben, amely az adózást sem kerülte el. Rövid tanulmányomban kizárólag azt vizsgálom, hogy az okos adózás és okos adóadminisztráció fogalmak milyen tartalmat jelentenek, mit érthetünk alatta, van-e már kialakult fogalmi kerete. Nem előreszaladva a következtetésekre teljesen egyértelmú, hogy ez egy új és folyamatosan új tartalommal megtöltött fejlődő fogalom, amely mindenképpen a modernizációt célozza meg, a fogalom megközelítése és spektruma ugyanakkor teljesen heterogén.

Az okos adózás, mint fogalom jelentéstartalmának sokszínűsége talán azzal szemléltethetô a legjobban, ha beütjük a szót az internetes keresőbe. Ennek eredményeként kevés magyar nyelvű tanulmányt vagy cikket találunk. A legelsőként mindenestre kiemelném Bordás Péter tanulmányait ${ }^{498499}$, amelyek a legátfogóbban kívánják tisztázni az okos adózás fogalmát, valamint néhány adótanácsadó cég egy-egy bejegyzése kerül felkínálásra. Az angol nyelvű keresés ennél valamivel bővebb tartalmat kínál.

Richard Bird 2010-ben írt tanulmányában jól összefoglalta az azóta jobban kibontott elemeit az okos adózás folyamatának. Az okos adózás stratégia magában foglalja adózók motiválását az adókötelezettségek teljesítésére, azok teljesítésének folyamatos monitorozását, megfelelő kockázatkezeléssel és a szankciók megfelelő alkalmazásával ezek hatékonyságának növelését ${ }^{500}$. Előremutató szervezeti javaslatai alapján célszerű a nem produktív ellenőrzési típusok elhagyása (mint például a magánszemélyek bevallásának ellenőrzése), egyes hagyományosan az adóhatóságok által ellátott tevékenységek kiszervezése és a korábbinál sokkal nagyobb hangsúlyt kell helyezni a nagy adózók átvilágítására, akik nem kizárólag adófizetők, hanem a bérek és a partnerek által megfizetett közvetett adók vonatkozásában maguk is adóbeszedői pozícióban vannak. Ez a megközelítés mindenképpen egy újszerű megközelítése az adóhatóság funkcióinak, viszont viszonylag szúk tartalmát fedi le a fogalomnak.

Gregory Mankiw volt elnöki tanácsadó, egyetemi tanár az okos adó kifejezést egyértelműen a Pigou-típusú környezetvédelmi célt szolgáló adóra érti kizárólagos jelentéstartalommal ${ }^{501}$. Ezen adók - értve ezalatt különösen az üzemanyagokat terhelő adókat - a „,szennyező fizet” elv alapján kivetett adók, amelyek ösztönzôleg hatnak a negatív környezeti externáliák csökkentése irányába.

\footnotetext{
498 BORDÁs Péter: Smart taxation: Okos adózás a hazai adórendszerben. Közjogi Sz̨emle, 2018/3. sz. pp. 47-52

499 BORDÁs Péter: Okos adózás, mint a fenntartható adójog pillére? Iustum Aequum Salutare XV. 2019. 17-25. 03 BordasP IAS 2019 3.pdf (ppke.hu) (Letöltve 2021.01.10-én)

500 BIRD, Richard: Smart Tax Administration. Economic Premise, The World Bank (Poverty Reduction and Economic Management Network), 2010.

.https://openknowledge.worldbank.org/bitstream/handle/10986/10152/573980BRI0EP360Box353747B01 PUBLIC1.pdf? sequence $=1$ \&isAllowed $=\mathrm{y}$

501 MankIW, N. Gergory: Smart Taxes: An Open Invitation to Join Pigou Club. Easter Economic Journal, 2009/35. 14-23. https://scholar.harvard.edu/files/mankiw/files/smart taxes.pdf
} 
Bordás Péter a fogalom meghatározó elemének tekinti a fenntarthatóság kérdését. Mankiwhoz részben hasonlóan szúk értelemben azon adókat felelteti meg e fogalomnak ${ }^{502}$, amelyeknek hatása van a fenntarthatóságra, ezen belül hangsúlyosan a környezetvédelemre. Ez azonban már egy sokkal tágabb fogalomkör előtt nyitja meg az ajtót, hiszen ez már érinti az adórendszer és az adópolitika kérdését is. Bordás Péter definíciója szerint az okos adórendszer „mind az állam, mind az adózók számára gazdaságilag hatékony, eredményes, fenntartható és globális hatásokra reagáló adózást, adóztatást eredményez, felhasználva a korunk által nyújtott okos megoldásokat, technikai vívmányokat, beépítve ezeket az adójogi szabályozás egészébe.” Ez egy ideális adórendszert feltételez, amely mindig, mindenkor a leghatékonyabb és leginkább a fenntarthatóságot szolgálja.

Kocsis Zsolt az EY partnere szerint az „okos adózás alatt azt értjük, hogy egységnyi idő alatt mennyi értéket tudunk teremteni a vállalatoknak." ${ }^{503}$ Ugyancsak az EY munkaanyaga ${ }^{504}$ szerint az okos adózás elsősorban a fiatal vállalkozások 'compliance'-terheit hivatott enyhíteni. Ugyanez a munkaanyag négypontos ajánlást tett közzé az okos adózásra vonatkozóan:

1. Megfelelő küszöbérték meghatározása a hozzáadottérték-adót illetően.

2. Az oktatás támogatása a kis- és középvállalkozások részére, amely támogatás a költségek levonhatóságában nyilvánul meg, függetlenül attól, hogy ki az oktató.

3. Az adókötelezettségek teljesítésének egyszerűsítése és digitalizálása, példaként emelném ki a számviteli és az adóügyi nyilvántartások kettőségének megszüntetésére tett javaslatot vagy a Magyarországon már lényegében megvalósult számlázási digitalizációt, amely alkalmas az adóbevallás összeállítására is. Ezen ponthoz kapcsolódóan kiemelném még az új vállalkozások digitális oktatását és az okos, például határidôkre emlékeztetô szoftverek alkalmazását.

4. Az üzletrész-átadás egy releváns javadalmazási forma a vállalkozások startup fázisában. A vállalkozás bizonyos bevételi küszöbe alatt ez a javadalmazási forma mentes lehetne az azt terhelő adóktól beleértve a jövedelemadókat vagy társadalombiztosítási hozzájárulást.

Ez a javaslatcsomag elsősorban az adónemre vonatkozó kedvezmények, lehetőségek kibővítésére alapozza az ügyfélközpontú adóztatás modelljét, ezzel kitöltve a fogalom lényegét.

Az Európai Unió Bizottsága kvázi eszközként tekint az okos adózási metódusokra, amely célja nem kizárólag a költségvetési bevételek növelése, hanem a gazdasági növekedés, a foglalkoztatottság, a beruházások előmozdítása vagy éppen a kiegyensúlyozott verseny és a társadalmi egyenlőség támogatása. ${ }^{505}$ A Bizottság az okos adózást mint módszert tehát elsősorban az adórendszert érintően tartja követendőnek, amely során a hatékony adózás három sarokpontjaként jelöli meg a munkát terhelő adók csökkentését, az adólap növelését és az adócsalás elleni küzdelmet.

\footnotetext{
502 BORDÁs i. m. (2019) p. 19.

503 Kocsis Zsolt: Erôsítse meg cégét okos adózással! EY Magyarország, 2020.11.22. https://www.ey.com/hu hu/tax/erositse-meg-ceget-okos-adozassal (Letöltve 2021.01.13.)

504 EY: Smart Taxation Policy Paper. https://www.citizen-entrepreneurs.com/wpcontent/uploads/2018/10/Smart-Taxation-Policy-Paper-EY-G20YEA.pdf(Letöltve: 2021.01.13.)

505 EC: Public Finances and Taxation. Smart Taxation. https://ec.europa.eu/info/business-economyeuro/growth-and-investment/structural-reforms/public-finances-and-taxation en\#smart-taxation (Letöltve: 2021.01.13.)
} 
Lehetséges olyan értelmezés is ennek nyomán, hogy minden új szabály vagy lehetőség „okos” minősítést kaphat, amely a kitüzött adópolitikai célt a korábbinál jobban, hatékonyan valósítja meg. Fontos, az „okosság” fogalmába beleértett követelmény ugyanakkor az is, hogy ez a megoldás mind az állam mind a táradalom szempontjából előnyös (tehát például a bevétel-növekedést nem adóemeléssel érjük el), valamint egyszerû és költséghatékony mind az adóhatóság mind adózó oldalán.

Láthatjuk tehát, hogy még az adójogi szférában is eltérő aspektusok érvényesülnek az okos adózás, mint fogalom vizsgálatakor. Okos adóról vagy okos adórendszerről csak ideáltipikus esetben beszélhetünk, amelyek esetében egy adott adónem szabályai vagy az adórendszer egésze kimeríti az adott időszak és lehetőségek minden fogalmi elemét, ezért ezeket nem vonom az okos adózás fogalmába. Az okos adózás fogalmának körül határolásához Bordás Péter ábráját használtam fel, ugyanakkor az egyes halmazoknak az általa felvetetteknél szűkebb jelentéstartalmat tulajdonítok a fentiek miatt. Az okos adózás fogalmi körébe tehát okos adók helyett okos adónemszabályokat, okos adóigazgatás helyett okos adóeljárási megoldásokat vonok be.

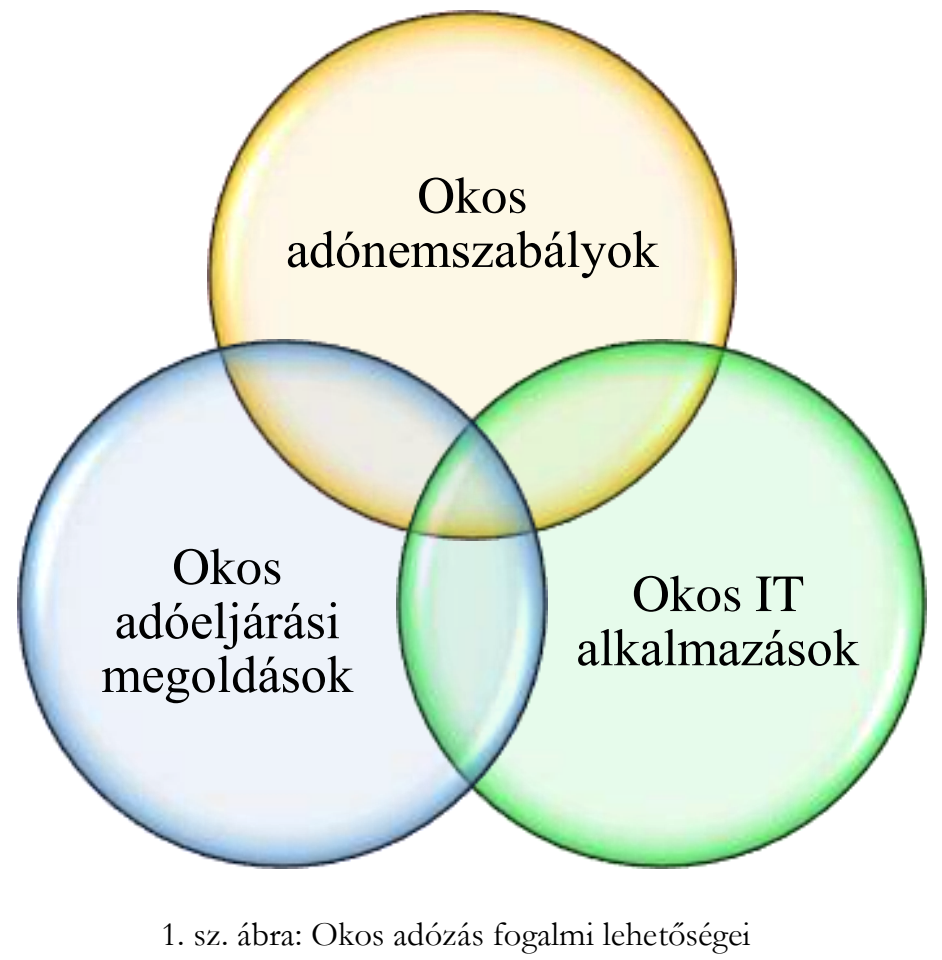

Forrás: Bordás Péter szerkesztése alapján lásd BORDÁs (2019) 19.

Okos adóigazgatás az én álláspontom szerint jellemzően azon megoldások halmaza, amely az okos adóeljárási szabályok és az okos IT alkalmazások valamelyikébe vagy mindkettőbe besorolható, tehát ugyanezen diagramon belül egy szűkebb területet lefedő jelentéstartalom.

A következő fejezetben olyan jelenleg már létező vagy a tervezőasztalon fekvő adózási megoldásokat, modelleket érintek, amelyek a fenti ábra valamely kategóriájába bizonyosan besorolható, a legtöbb esetben legalább két, de esetenként mindhárom halmaz kritériumait teljesítik.

Az okos adózás általam szúk jelentésébe tartozó megoldások közös jellemzője, hogy a következő feltételekből legalább kettőnek megfelelnek: 
- valamely adópolitikai célt szolgál (adócsalások elkerülése, bevételek teljesülése, környezettudatosság, fenntarthatóság stb.)

- az adózást egyszerúbbé és/vagy költséghatékonyabbá teszi,

- a megvalósítása információtechnológiai eszközrendszert igényel.

\section{Okos adózási megoldások}

A következőkben olyan új, modern metódusok és eszközök adózásba történő beépítéséről írok röviden, amelyek a fenti fogalmi elemek alapján joggal sorolhatóak az okos adózás fogalomkörébe.

\section{Új lebetöségek a kommunikáaióban}

A digitális megoldások új kaput nyitottak az adóhatóságok és az adózók közötti kommunikációba. A hagyományos postai, telefonos, személyes kapcsolattartást kiegészíthetik vagy felválthatják más megoldások, amelyek egyszerúbb, célszerúbb, költséghatékonyabb és praktikusabb, egyszóval „okos” megoldásokat kínálnak. Az OECD által 2019-ben megjelentetett gyakorlati útmutató számos nemzetközi gyakorlatot említ, amiből néhányat kiemelek, mint új, digitális hátterü okos alkalmazás. ${ }^{506}$

Talán az egyik legegyszerúbb, de igen praktikus „,nudging” technikát alkalmazza Szingapúr SMS küldésével azon adózóknak, akik korábbi időszakban elmulasztották vagy késedelmesen nyújtották be bevallásukat. Elterjedt nemzetközi gyakorlat a bevallás adóhatóság általi elkészítése, ami Magyarországon a korábban bevezetett személyi jövedelemadót követően 2021. július 1-tôl az általános forgalmi adót illetően is bevezetésre kerül. Ausztráliában a jövedelemadó vonatkozásában a hagyományosan a bevallás elkészítésének teret adó myTax oldal 2016-tól kibővült a myDeductions alkalmazással, ami lehetőséget ad az évközbeni költségek rögzítésére, így a bevallás ez alapján automatikusan elkészíthető. Oroszországban a helyhatóság által az ingatlanok után kivetett adó kapcsán az adózóknak lehetôségük van egy alkalmazás révén képet kapni a nyilvántartott tulajdonosi pozícióikról, így előre tudják jelezni esetleges kifogásaikat a kivetés kapcsán.

A kapcsolat megbízhatóságának digitális eszközei is előremutatók mind az adatvédelmi biztonság mind az egyszerűség tekintetében. Így lehetőség van például az adóhatósági alkalmazásokban való belépés során különböző belépési kódok helyett biometrikus azonosítást alkalmazni. Új-Zéland és Ausztrália adóhatósága az ügyfélszolgálat telefonos megkeresésekor hangfelismerést alkalmaz, így beazonosítva az ügyfelet. Dél-Afrikában az adóigazgatási jogszabály rendelkezik az arc-, hang-, ujjlenyomat és retina felismerés alkalmazásáról. Ezek új technikák kimutathatóan gyorsabbá teszik a kapcsolatfelvételt, így időt és költséget takarítva meg mindkét félnek. Érdemes a fejlesztések irányaként a „mobile first" elvet megemlíteni, amely általánosságban igaz a webalapú fejlesztésekre nézve, sok ország ennek szellemében a mobilapplikációval elérhető szolgáltatások körét bővíti hangsúlyosan.

Az adóhatóságok igyekeznek honlapjukon a legaktuálisabb információkkal ellátni adózóikat az adókötelezettség határidőben és megfelelő tartalommal történő teljesítéséhez, azonban ebben a tekintetben is beszélhetünk új megoldásokról. Az ún. okos portál lehetôvé teheti a

506 OECD: Technologies for Better Tax Administration A Practical Guide for Revenue Bodies. OECD Publishing, Paris, 2016. https://doi.org/10.1787/9789264256439-en 
kétirányú kommunikációt chat, video tanácsadás útján, de alkalmazható mesterséges intelligenciával történő válaszadási protokoll is ${ }^{507}$.

Talán az egyik legfejlettebb rendszer jelenleg a Dél-Koreában alkalmazott Hometax ${ }^{508}$. Ez egy integrált portál, ahol adózók szinte minden adózási funkciót elérhetnek és az adóbevallással, az adó befizetésével kapcsolatos minden múveletet el tudnak végezni. Ennek a rendszernek a kiépítése 2002-ben kezdődött és az egyes modulokat lépésenként integrálták. Ez a rendszer magába foglalja az öröklési adó kivételével minden adónemre vonatkozó bevallás elkészítésének és megfizetésének lehetôségét (ez az előre elkészített bevallástervezet jóváhagyását jelenti), az adóigazolások kiállitását, az online pénztárgép és az online számlarendszert, interaktív ügyfélszolgálatot, elektronikus tájékoztatást (e-Notice) és több más lehetőséget, mindezeket mobilalkalmazásként is elérhetővé téve.

A modernizáció nemcsak az adózó-adóhatóság kapcsolatát érinti, hanem az adóbeszedés hatékonyságát modern technikai eszközökkel más szereplőkkel történő kapcsolat fejlesztésével is növelni lehet. Az Eurofisc keretében múködne az elsődlegesen az elektronikus kereskedelem ellenőrzésére létrehozott CESOP (Central electronic system of payment information) adatbázis, amelynek célja adóhatóságok és a pénzforgalmi szolgáltatók együttmúködésének fokozása elsősorban ez e-kereskedelem valós vertikumának feltárásában. A Bizottság 2018-ban terjesztette elő erre vonatkozó javaslatát509, a Tanács pedig 2020-ban döntött ${ }^{510}$ a CESOP létrehozásáról, amely 2024-től múködne. A pénzforgalmi szolgáltatók, mint a fizetést lebonyolító független szervezetek adatokkal rendelkeznek az egyes ügyletekről, amelyekből megállapítható az adókötelezettség. Önmagában a fizetésre vonatkozó adatok még nem jelentenek kész tényeket egy-egy ügyletre vonatkozóan, hiszen nem feltétlenül tudjuk, hogy minek az ellenértéke cserél gazdát. A pénzforgalmi szolgáltatóktól származó információk tehát még további feldolgozást igényelnének, az együttmúködés azonban sok előnnyel kecsegtet ${ }^{511}$.

Dániában az ügyfél hozzájárulásával az adóhatóság automatikusan közli a szükséges adatokat az ügyfél hitelkérelméhez, amely rendkívül meggyorsíthatja a folyamatot. 2015-ben közel 500.000 esetben került sor adattovábbításra.

\section{Valós idejü adatszolgáltatás}

$\mathrm{Az}$ adóellenőrzés területén okos megoldások elsősorban a valós idejű (real time) adatszolgáltatások kapcsán kerültek előtérbe. Ezen adatszolgáltatások elsődleges célja az adóelkerülés csökkentésével az adórés szúkítése. A valós idejü adatszolgáltatásoknak a hozzáadottérték-adó területén több formája is létezik, de közösségi konszenzus nem

\footnotetext{
507 Technologies for Better Tax Administration pp. 86-87.

${ }^{508}$ Hometax World-Class Electronic Tax Administration Service. National Tax Service, Republic of Korea, 2016. https://www.mois.go.kr/cmm/fms/FileDown.do?atchFileId=FILE 00070312AUWtGj \&fileSn=0. (Letöltve: 2021.02.26.)

${ }^{509} \operatorname{COM}(2018) 812$ final Javaslat a Tanács 2006/112/EK irányelvnek a pénzforgalmi szolgáltatók számára egyes kötelezettségek bevezetése tekintetében történő módosításáról https://ec.europa.eu/transparency/regdoc/rep/1/2018/HU/COM-2018-812-F1-HU-MAIN-PART-1.PDF (Letöltve: 2021.01.14.)

510 A TANÁCS 2020. február 18-i (EU) 2020/283 Rendelete a 904/2010/EU rendeletnek a héacsalás elleni küzdelem érdekében folytatott közigazgatási együttműködés megerősítésére irányuló intézkedések tekintetében történő módosításáról.

511 Merkx, Madaleine - JAnSSEN, Anne: A New Weapon in the Fight against E-Commerce VAT Fraud: Information from Payment Service Providers. International VAT Monitor, IBFD, 2019. 231-239. https://research.ibfd.org/collections/ivm/printversion/pdf/ivm 2019 06 e2 3.pdf
} 
született még erről, aminek az oka az, hogy ez költségekben mérhető terhet jelent a vállalkozásoknak. Éppen ezért a tagállamok eltérő ütemben vezetik be a valós idejű adatszolgáltatás kötelezettségét, amely a digitalizáció egyik fontos megjelenése az eljárásokban ${ }^{512}$. Ezek tehát olyan megoldások, amelyek a fentiekben ábrázolt mindhárom halmazt érintik.

Az egyik ilyen típusú adatszolgáltatás a Standard Audit File for Tax (SAF-T), amely lényegében az adózók által szolgáltatott sztenderdizált adatcsomag, és segíti az adóhatóságokat a gazdasági folyamatok jelen idejű nyomon követésében. Ezt elsőként Portugália, Ausztria és Luxemburg vezette be, jelenleg több más tagállam vizsgálja az általánossá tétel lehetőségét. Abban is van eltérés, hogy ezt egyes államok kötelezővé tették minden gazdálkodó részére, mások adózói igény alapján teszik lehetôvé.

A másik igen sikeres adóhatósági eszköz az online számlázás. Az online számlarendszer bevezetése kapcsán Spanyolország elsősége említhető meg (Sistema de Información), Magyarország másodikként vezette be ezt a rendszert 2018-ban. Emellett ki kell emelni Olaszország klíringrendszerét (Sistema di Intercambio ${ }^{513}$ ), amely adóhatósági jóváhagyáshoz köti a számla kibocsátását. Ez lényegében a legelőrehaladottabb online ellenőrzési lehetőség, amely rendkívül sikeres, Olaszország 2019-ben 4 milliárd euró többletbevételt könyvelhetett el hozzáadottérték-adó (héa) adónemben ${ }^{514}$.

\section{Megosztott fizetés}

Megítélésem szerint „okos” eljárási eszköz az ún. split payment. Ennek a megoldásnak az elsődleges célja a hiányzó kereskedős csalások megelőzése azáltal, hogy az ellenérték banki utalása során a hozzáadottérték-adó összege nem a számlakibocsátó, hanem az adóhatóság részére kerül továbbításra. Ez természetesen teljesen más szemléletet követel meg az adóhatóságok és a gazdálkodók részérôl, valamint nem nyújt megoldást a készpénzes ügyletekre. Az utóbbi években néhány állam kísérletet tett az ún 'megosztott fizetés' modelljének bevezetésére ${ }^{515}$. Olaszországban csak az ún. B2G (business to government) viszonylatban kötelező, azaz a törvényben külön meghatározott közhatalmi szerveknek kötelező az adót közvetlenül az adóhatóságnak utalni. Ez a szabályozás 2017-től kiegészítésre került közvetve vagy közvetlenül állami tulajdonban álló társaságok fizetési kötelezettségeire is. Ettől eltérő rendszer lépett hatályba 2017. október 1-től Lengyelországban, ahol az adót is tartalmazó számlát befogadó adóalanyok részére egy lehetőség, azaz a szabályozás első két évében nem volt kötelező ennek alkalmazása. A megosztott fizetés 2019. szeptember 1-től azonban az ügyletek egy meghatározott csoportjában kötelezővé vált akkor, ha annak értéke elérte a törvényi limitet (15000 PLN).

Az ellenérték megosztása nettó- és adóösszegre a bank feladata, aki az adót a számlát kibocsátó adóalany nevében utalja át az adóhatóság részére. Amennyiben az adóalany ezt az

512 BAL, Aleksandra: VAT Trends in Europe: Digitalization and Real-Time Filing. Tax Notes International, 2019.02.18. 717-723. https://www.taxnotes.com/tax-notes-international/value-added-tax/vat-trendseurope-digitalization-and-real-time-filing/2019/02/18/293k6 (Letöltve: 2021.01.08.)

513 https://www.avalara.com/vatlive/en/country-guides/europe/italy/italy-sdi-real-time-e-invoices.html (Letöltve 2021.01.12.)

514 ASQUITH, Richard: Italy SdI VAT e-invoicing raises €4bn https://www.avalara.com/vatlive/en/vatnews/italy-sdi-vat-e-invoicing-raises--4bn.html (Letöltve: 2021.01.12.)

515 PrätZler, Robert C.: Split Payments in VAT Systems - Is This the Future? International VAT Monitor, IBFD, $2018 . \quad$ április 66-70. https://www.ibfd.org/sites/ibfd.org/files/content/marketing/Journal Previews/IVM/International-VATMonitor-Mar2018.html (Letöltve: 2021.01.19.) 
opciót választja, elkerüli a partnere adókötelezettségének nem teljesítéséből származó mögöttes felelősséget. Emellett számos más előnyt is élvez adózó, például a megosztott fizetéssel érintett ügyletek esetében alacsonyabb az esetleges bírságösszeg, nincs késedelmi pótlék adókülönbözet esetén. Romániában az adóalanyok közötti fizetésre szintén alkalmazandó a megosztott fizetés azzal, hogy a vevő csak a nettó összeget utalja partnerének, az adót pedig egy kijelölt héa számlára kell megfizetnie. Itt tehát nem a bank végzi a megosztást, hanem az ügyfél. Több tagállamban kezdődött közös gondolkodás egy ilyen fizetési mód bevezetéséről, itt említeném meg az Egyesült Királyságban és Franciaországban jelenleg kidolgozás alatt álló terveket, amelynek a lényege az, hogy egy közvetítő szereplő kötelezettsége lesz a megfelelő adómértékkel számolt hozzáadottértékadó összegének átutalása.516 Fontos megemlíteni, hogy az adóbevételekre gyakorolt pozitív hatása mellett rendkívül nagy adminisztrációs terhet jelent az adózóknak. Negatívumként említhető még a termékértékesítés végzőt vagy a szolgáltatásnyújtót érő kedvezőtlen cash flow mérleg, hiszen a levonható adót már nem fogja tudni ellentételezni a megkapott adóösszeggel. Ez azt jelenti, hogy folyamatosan visszaigénylő pozícióban lesz az adózó, mivel a partnerének felszámított adót nem neki fogják megfizetni és nem ő vallja és fizeti be a törvény által előirt esedékességi időpontban. A megosztott fizetés tehát nem teljes sikertörténet, a legelőrehaladottabb lengyel szabályozás többszöri módosítása is azt jelzi, hogy van még mit tökéletesíteni rajta. ${ }^{517}$

\section{Blokeklánc technológia}

Még a valóságba nem átültetett elképzelés a blokklánc mint új, innovatív technológia felhasználása a számlázási folyamatokban. Ainsworth és Shact tanulmányukban ${ }^{518}$ egy jövőbe mutató megoldást vázolnak fel a hiányzó kereskedős csalások és a körhintacsalások kiszűrésére, amelynek középpontjában egy ilyen technológia alkalmazása áll. A tagállami adóhatósági adatbázisok jelenleg állami szinten centralizáltak, a kriptográfiai úton előállított számlák viszont decentralizáltan kerülnek nyilvántartásra a kriptovalutákhoz hasonlóan. A centralizált adatbázis rendkívül nagy hátránya, hogy ki van téve a kibertámadásoknak ${ }^{519}$, amilyenre például sor került Bulgáriában 2019-ben ${ }^{520}$. Ennek megoldásaként az ún. diszruptív blokklánc technológia megfelelő hitelesítéssel tenné lehetôvé a gazdasági folyamatok rögzítését és nyomon követhetőségét, így a tranzakciók lényegében egy teljesen

516 GRYZIAK, Bartosz: Split Payment across the European Union - Review and Analysis. International VAT Monitor, $\quad$ IBFD, 2020.24. https://research.ibfd.org/\#/doc?url=/collections/ivm/html/ivm_2020 01 e2 2.html (Letöltve: 2021.01.19.) Gryziak három fajtáját különbözteti meg a megosztott fizetési módszernek: a) az elkülönített számla módszere, mely során a fizető fél teljesíti az adó összegének megfizetését egy arra szolgáló külön számlára; ezt a módszert alkalmazza jelenleg Románia, Lengyelország, Bulgária b) kötelező visszatartás módszere közvetítő útján; jelenleg ilyen koncepció van kidolgozás alatt Franciaországban és az Egyesült Királyságban c) vegyes módszer, amelyhez az olasz és cseh példát sorolja.

517 UChMAnskA, Urszula: Split Opinions about the Split-Payment Mechanism? A Discussion of the Polish Example. International VAT Monitor, IBFD, $2019 . \quad$ 159-165. https://research.ibfd.org/collections/ivm/printversion/pdf/ivm 201904 pl 1.pdf (Letöltve: 2021.01.18.) 518 Ainswoth, Richard T. -SHACT, Andrew B.: Blockchain Technology Might Solve VAT Fraud. Tax Notes International, 2016. szeptember 26. https://www.law.upenn.edu/live/files/5954-83-tni-1165-september-262016pdf (Letöltve: 2021.01.11.)

519 JAFARI, Saschaa: Combining Modern technology and Real-Time Invoice Reporting to Combat VAT Fraud: No Revolution, but Technological Evolution. International VAT Monitor, IBFD. 2020. 139-143. https://research.ibfd.org/\#/doc?url=/collections/ivm/html/ivm_2020 03 e2 2.html (Letöltve: 2021.01.11.)

520 Statement on the data breach in the National Revenue Agency of Bulgaria http://www.oecd.org/tax/transparency/documents/statement-on-the-data-breach-in-the-national-revenueagency-of-bulgaria.htm (Letöltve: 2021.01.12.) 
decentralizált rendszerben, a tagállamok adóhatósági adatbázisától függetlenül rögzülnének azok releváns adataival. Ez valóban lehetôvé tenne egy teljesen online, valós idejü kockázatelemzést, amelyet rendkívül rövid időn belül, megfelelő informatikai háttérrel másodpercek alatt el lehet végezni. Azt is ki kell emelni, hogy ezzel az áruk útvonalának nyomon követhetősége lényegében egy kattintással megoldható lenne, vagy ahogy a hivatkozott tanulmányban szerepel, a számlát egy kézi szkennerrel leolvasva azonnal feltárható a kereskedelmi lánc.

Ez a gazdasági események követésének új technikája az adókötelezettség teljesítését és az adóbeszedést is automatizálná, azaz az adóhatóság által követett módon egy lépésben azonnal megtörténhetne az adó áthárítása, az adó megfizetése és levonása annak visszatérítésével521. Ez tehát még csak egy vízió, de jól látható, hogy a digitalizáció milyen innovációs lehetôségeket hordoz a teljes héa-rendszerre vonatkozóan.

A blokklánc technológia és a split payment egységes alkalmazása az alapja egy új innovatív ötletnek, amelynek a neve Automatikus Héa Beszedési Mechanizmus (Automated VAT Collection Mechanism). Az ötlet ${ }^{522}$ célja eredetileg az eltérő tagállamok között létrejött B2C ügyletek során keletkezett héa beszedése, de a megoldási javaslat ezen túlmutat. A lényeg, hogy a fentebb már bemutatott blokklánc technológia alkalmazásával létrejött ügyletek ún. okos szerződések ${ }^{523}$ útján jönnek létre. A blokklánc technológiával megkötött okos szerződés a héa megfelelő tagállamba történő utalását a fogyasztó pénzügyi szolgáltatójától és a kereskedőtől kapott információra építve végezné el. Az okos szerződés a kettős verifikációt követően az átutalást a SWIFT rendszeren keresztül végezné, kalkulálva az adó és az adóalap összegét, majd az előbbit a fogyasztás helye szerinti tagállamba továbbítaná. Mint minden jövőbe mutató ötletnek ennek is van hátránya, elsősorban a blokklánctechnológia nyilvánossága miatt ez a folyamat a fogyasztó részéről a magántitok, a vállalkozó részérôl pedig az üzleti titok sérelmével járna.

A blokklánc technológia és az okos szerződések adózásban történő alkalmazása a középtávú jövőbe mutat, Imram Bashir grandiózus, technikai részleteket feldolgozó könyvében ezt 2020 és 2050 között látja megvalósíthatónak. ${ }^{224}$

\footnotetext{
${ }^{521}$ BORSELLI, FABRIZIO: VAT Fraud, Cryptocurrencies and a Future for the VAT System. International VAT Monitor, $\quad$ IBFD, $2019.2179-186$. https://research.ibfd.org/collections/ivm/printversion/pdf/ivm 201905 e2 2.pdf (Letöltve: 2021.01.11.) 522 MÜLLER, Robert: Proposal for an Automated Real-Time VAT Collection Mechanism in B2C E-Commerce Using Blockchain Technology. International VAT Monitor, IBFD. $2020 . \quad 135-138$. https://research.ibfd.org/\#/doc?url=/collections/ivm/html/ivm 202003 e2 $3 . h t m l$ (Letöltve: 2021.01.11.)

523 Smart contract vagy okos szerződés egy magát automatikusan végrehajtó számítógépes kód, amely a felek közötti ügylet során jön létre és a blokkláncban kerül tárolásra. Ez a szerződés akár hagyományos megállapodást is jelenthet, amely a szerződés rendelkezéseit, mint például az ellenérték utalása automatikusan teljesíti. A megállapodás a bányászati tevékenység során többszöröződik, így az integritása biztosított. LEVI, Stuart D. - LIPTON, Alex B.: An Introduction to Smart Contracts and Their Potential and Inherent Limitations. Harvard Law Forum on Corporate Governance. 26.05.2018. https://corpgov.law.harvard.edu/2018/05/26/an-introduction-to-smart-contracts-and-their-potential-andinherent-limitations/ (Letöltve 2021.01.13.) (Megjegyzem, hogy az okos szerződés ötlete Nick Szabotól a Washingtoni Egyetem végzős hallgatójától származik 1996-ból)

${ }^{524}$ BASHIR, Imran: Mastering Blockchain Distributed ledger technology, decentralization, and smart contracts explained. (Second edition - Fully revised and updated) Packt, Birmindham, 2018. 892. https://users.cs.fiu.edu/ prabakar/cen5079/Common/textbooks/Mastering_Blockchain_2nd Edition.pdf (Letöltve 2021.01.13.)
} 


\section{Okos adózás tágabb értelemben}

\section{Új kapcsolati formák}

Az okos adózás tágabb értelmezése lehetőséget ad az adózás olyan formáinak vizsgálatára, amely nem feltétlenül osztja az első fejezetben adott definíció minden elemét. Itt elsősorban olyan adószabályok és eljárási normák említhetőek, amelyek kiemelten fontos adópolitikai célt valósítanak meg önmagukban, de nem feltétlenül jelent egyszerűsítést az adózás tekintetében, illetve nem feltétlenül támaszkodik újszerú technikai megoldásra.

Bizonyos, hogy nem csak a technológiára épített módon lehet előrelépést elérni az adóztatás modernizációjában - bár a fentebb részletezett kapcsolattartást kétségtelenül egyszerúbbé teszik ezen új eszközök - hanem a szemlélet innovációjával is.

Az okos adóeljárási eszközök nemcsak kifejezetten egy-egy részletszabályban nyilvánulhatnak meg, hanem egy adóztatási koncepcióban is testet ölthet a járulékos szabályozási keretek rögzítése mellett. Koncepción jelen esetben az adózó és az adóhatóság kapcsolatának újradefiniálását értem, amely már több mint egy évtizede megjelent különböző országokban. Az adóhatóság és adózó hagyományos, a német jogelméletben gyökerező, alapvetően alá-fölérendeltségen és kötelezettségek meghatározásán alapuló viszony kiegyensúlyozása álláspontom szerint kifejezetten hatékony irányt jelent az adóztatásban. Említhetném az adózási ergonómia előmozdításaként a Magyarországon néhány éve bevezetett támogató eljárást is, amely a hagyományos ellenőrzési eljárások mellett létező kiegészítő eszköz az adófizetési hajlandóság előmozdítása, adózó támogatása érdekében.

Néhány országban már régóta utat tört egy új, kiemelt együttmúködésen alapuló módszer. Bár a különböző országokban megjelent változatok között sok eltérés mutatkozik, ezen új adóztatási megoldás egyértelmúen a mellérendeltséget, ezzel együtt a rugalmasságot, bizalmat és az együttmúködést helyezi a kapcsolat fókuszába. Mindazonáltal ezen új módszernek is a fő célja, hogy adózó a helyes adóösszeget idôben fizesse meg a nemzeti költségvetésbe. A kölcsönös bizalom és együttmúködés jegyében mindkét fél valós időben látja el információval a másikat az adózói oldalon a z adókötelezettség megfelelő teljesítéséhez, adóhatósági oldalon pedig az adózó mûködéséről megfelelő információval való rendelkezéshez. Példaként említhető az ún. együttmúködő adóztatás Ausztráliában (cooperative compliance) vagy horizontális monitoring Hollandiában és Ausztriában ${ }^{525}$. Az egyes modellek között jelentős különbségek is felfedezhetőek elsősorban a bevont adózói kört illetően ${ }^{526}$. A már 2005-ben Hollandiában bevezetett horizontális monitoring alkalmazása lényegében minden adózó számára nyitva áll, néhány ágazat, tevékenységi típus jelent kivételt. Ausztráliában az ebben a formában 2015 óta alkalmazott együttmúködési modell ezzel szemben csak a legnagyobb és legmegbízhatóbb paraméterekkel rendelkező adózói kör (key taxpayers) számára teszi lehetôvé a kiemelt együttmúködés alkalmazását.

\footnotetext{
525 ENACHESCU, Janina et al.: Horizontal Monitoring in Austria: subjective representations by tax pfficials and company employees. Springer, 2018. https://doi.org/10.1007/s40685-018-0067-1

526 BAlHarová, Mirka: Cooperative Compliance models int he Netherlands and Australia: truly based ont he principles of legal certainty and equality? LL.B. Thesis, The hague University, 2016. https://www.academia.edu/29262192/M Balharova Cooperative Compliance Models in the Netherland s and Australia Truly Based on the Principles of Legal Certainty and Equality (Letöltve: 2021.01.12én)
} 
Természetesen ezt a rendszert is érték kihívások, elsősorban a nagyobb mozgástér által elért „megállapodások” kapcsán ${ }^{527}$. Konklúzióként annyi elmondható, hogy ez az új kapcsolati minőség egyrészt szemléletbeli, másrészt eljárásjogi innovációt is megkövetel, nem beszélve arról, hogy az adóigazgatásban is változást igényel, amelyet jól megalapozott oktatással lehet elérni.

\section{Ökoadók}

Ide sorolom a környezettudatosság és a fenntarthatóság szempontját megvalósító adónormákat, amelyek testet ölthetnek egy-egy adónem formájában (extern adók) vagy más adónemek szabályai közé építenek be környezetvédelmi szempontokat (például a megújuló energiahordozókra alkalmazott csökkentett héamérték $\left.{ }^{528}\right)$.

Az elmúlt évtizedekben több európai ország tett kísérletet ökológiai adóreform bevezetésére (Pl.: Németország 1983-1992 között) ${ }^{529}$, de az bizonyos, hogy az EU tagországokban az ökoadók részaránya alacsony ${ }^{530}$. Éppen ezért okos adórendszerről - ahogyan Bordás Péter vagy Mankiw felveti - ilyen értelemben nem beszélhetünk.

\section{Versenyképesség mint az okos adóztatás fokméróje}

$\mathrm{Az}$ okos adózás tágabb fogalmi köre kiegészíthető a versenyképességgel mint összehasonlítható szempontrendszerrel. A versenyképességet egy adott ország adórendszere a megfelelően alacsony adókulcsukkal és hatékony, az adózók részérôl könnyen teljesíthető adószabályokkal tudja elérni. Bár egy versenyképes adórendszer része lehet a fentebb részletezett adózási megoldások egy vagy több eleme, a versenyképességet, legalábbis gazdasági értelemben, elsősorban az adómértékek alakításával lehet előre mozdítani. Csak röviden térnék ki az OECD által alkalmazott módszerre ${ }^{531}$, amellyel a tagországok adórendszerének versenyképességét mérik össze évről évre, amely főként az egyes adónemek szabályozását veszi alapul ${ }^{532}$. Ez a mutató az adómértékek versenyképességét és az adórendszer semlegességének kombinált hatását monitorozza533. Fontos osztályozási szempont egy adónemre vonatkozó szabályok komplexitása vagy egyszerủsége, azaz az adókötelezettségek teljesíthetősége és az esetleges adócsökkentő tételek érvényesíthetősége.

\section{Konklúzió}

Az 'okos' jelző korunk divatos kifejezése, amelynek egyértelműen innovatív tartalmat kölcsönöz a köznyelv. Az okos adózás és okos adóigazgatás még nem jogi terminus

\footnotetext{
${ }^{527}$ DE WIDT, Dennis: Dutch Horizontal Monitoring: The Handicap of a Head Start. University of Exeter, 2017. https://www.diva-portal.org/smash/get/diva2:1142129/FULLTEXT01.pdf pp. 31-34. (Letöltve: 2021.01.12.)

${ }^{528}$ HerbaIN, Charléne A.: Shoul VAT Be the Nex Environmental Policy Tool? International VAT Monitor, IBFD, 2020. 69-73. https://research.ibfd.org/\#/doc?url=/collections/ivm/html/ivm 202002 e2 1. html (Letöltve: 2021.01.12.) A héa tekintetében éppen az adó hatékonyságát rontaná még több az általánostól eltérő adókulccsal adóztatott energiahordozó mint termék bevonása.

${ }^{529}$ Herich György: Nemzetközi adózás. Penta, Budapest, 2019. pp. 668-677.

530 2019-ben az ökoadók az EU 27 országa kormányzati bevételének 7 \%-át nem érték el, amely bevétel a teljes GDP 2, 3 \%-át tette ki. File:Environmental tax revenue by type and total environmental taxes as share of TSC and GDP, EU-27, 2002-2019 (million EUR, \%) .png - Statistics Explained (europa.eu) (Letöltve: 2021.01.27.) 531 International Tax Competitiveness Index (ITCI)

532 Már hetedik éve Észtország vezeti ezt a versenyt 2020-International-Tax-Competitiveness-Index.pdf (taxfoundation.org)

533 Magyarország 2020-ban ebben a rangsorban a 14. helyet foglalja el, az előkelő 4. helyet a társasági adó és a nemzetközi adószabályok kapcsán értünk el, a fogyasztási adók területén viszont csak a 35.-ek lettünk (36 országból)
} 
technicus, ugyanakkor egyre gyakrabban előforduló kifejezések. Éppen ezért célul tűztem ki annak vizsgálatát, hogy ezen fogalmak körébe milyen adójogi megoldások sorolhatóak. Igyekeztem elzárkózni az olyan tökéletes adójogi állapotot tükröző szóösszetételektől, mint okos adórendszer és okos adónem, de az okos adóigazgatás kifejezés is egy minden szempontból optimális, kizárólag modernizált metódusokkal dolgozó adminisztrációt feltételez. Megállapítottam, hogy okos adózás alatt okos adónemszabályok, okos adóeljárási megoldások és az innovációt lehetővé tevő IT alkalmazások összességét lehet érteni. Tanulmányomban sorra vettem azokat a megvalósult vagy még átgondolás alatt lévő technikai-adójogi megoldásokat, amelyek egy vagy több ismérvük alapján e fogalom körébe sorolhatók. Nem törekedtem a teljeskörűségre, hiszen az egy lehetetlen vállalkozás lenne. Azokat az új megoldásokat és ötleteket vetettem fel ezen csoportosítást segítségül hívva, amelyek a jelenkori adójogi gondolkodás fókuszában vannak, mindemellett besorolhatók a fogalom szélesebb értelemben vett értelmezési tartományába. Látható, hogy a technikai innováció és az adózás hatékonyságának növelése egy folyamat, az okos adózás pedig ennek a fejlődésnek az aktuális megvalósulási formáit fogja át.

\section{Felhasznált irodalom}

[1] Ainswoth, Richard T. -Shact, Andrew B.: Blockchain Technology Might Solve VAT Fraud. Tax Notes International, 2016. szeptember 26. https://www.law.upenn.edu/live/files/5954-83-tni-1165-september-26-2016pdf

[2] BAL, Aleksandra: VAT Trends in Europe: Digitalization and Real-Time Filing. Tax Notes International, 2019.02.18. https://www.taxnotes.com/tax-notesinternational/value-added-tax/vat-trends-europe-digitalization-and-real-timefiling $/ 2019 / 02 / 18 / 293 \mathrm{k} 6$

[3] Balharová, Mirka: Cooperative Compliance models int he Netherlands and Australia: truly based ont he principles of legal certainty and equality? LL.B. Thesis, The hague University, 2016. https://www.academia.edu/29262192/M Balharova Cooperative Compliance Mo dels in the Netherlands and Australia Truly Based on the Principles of Legal Certainty and Equality

[4] BASHIR, Imran: Mastering Blockchain Distributed ledger technology, decentralization, and smart contracts explained. (Second edition - Fully revised and updated) Packt, Birmindham, 2018. https://users.cs.fiu.edu/ prabakar/cen5079/Common/textbooks/Mastering_Bloc kchain 2nd Edition.pdf

[5] BIRD, Richard: Smart Tax Administration. Economic Premise, The World Bank (Poverty Reduction and Economic Management Network), 2010. https://openknowledge.worldbank.org/bitstream/handle/10986/10152/573980BR I0EP360Box353747B01PUBLIC1.pdf

[6] BORDÁs Péter: Okos adózás, mint a fenntartható adójog pillére? Iustum Aequum Salutare XV. 2019. http://ias.jak.ppke.hu/hir/ias/20193sz/03 BordasP \%20IAS 2019 3.pdf

[7] BORDÁs Péter: Smart taxation: Okos adózás a hazai adórendszerben. Közjogi Sz̨emle, 11. évf. 2018/3. sz. pp. 47-52.

[8] BORSELLI, Fabrizio: VAT Fraud, Cryptocurrencies and a Future for the VAT System. International VAT Monitor, IBFD, 2019. https://research.ibfd.org/collections/ivm/printversion/pdf/ivm 201905 e2 2.pd $\underline{f}$ 
[9] DE WIDT, Dennis: Dutch horizontal monitoring: The Handicap of a Head Start. University of $2017 . \quad$ Exeter, portal.org/smash/get/diva2:1142129/FULLTEXT01.pdf

[10] ENACHESCU, Janina et al.: Horizontal Monitoring in Austria: subjective representations by tax pfficials and company employees. Springer, 2018. https://doi.org/10.1007/s40685-018-0067-1

[11] GRYZIAK, Bartosz: Split Payment across the European Union - Review and Analysis. International VAT Monitor, $\quad$ IBFD, 2020 https://research.ibfd.org/\#/doc?url=/collections/ivm/html/ivm 202001 e2 2.h $\underline{\mathrm{tml}}$

[12] Herbain, Charléne A.: Shoul VAT Be the Nex Environmental Policy Tool? International VAT Monitor, IBFD, 2020. https://research.ibfd.org/\#/doc?url=/collections/ivm/html/ivm 202002 e2 1. h $\underline{\mathrm{tml}}$

[13] HeRICH György: Nemzetközi adózás. Penta, Budapest, 2019.

[14] Italy Sistema di Interscambio (SdI) real-time e-invoices. https://www.avalara.com/vatlive/en/country-guides/europe/italy/italy-sdi-realtime-e-invoices.html

[15] JAFARI, Saschaa: Combining Modern technology and Real-Time Invoice Reporting to Combat VAT Fraud: No Revolution, but Technological Evolution. International VAT Monitor, $\quad$ IBFD. $2020.2139-143$. https://research.ibfd.org/\#/doc?url=/collections/ivm/html/ivm_2020_03_e2_2.h tml

[16] Mankiw, N. Gergory: Smart Taxes: An Open Invitation to Join Pigou Club. Easter Economic Journal, 2009/35.

$14-23$. https://scholar.harvard.edu/files/mankiw/files/smart taxes.pdf

[17] Merkx, Madaleine - Janssen, Anne: A New Weapon in the Fight against ECommerce VAT Fraud: Information from Payment Service Providers. International VAT Monitor, IBFD, 2019. https://research.ibfd.org/collections/ivm/printversion/pdf/ivm_2019_06_e2_3.pd $\mathrm{f}$

[18] MÜLLER, Robert: Proposal for an Automated Real-Time VAT Collection Mechanism in B2C E-Commerce Using Blockchain Technology. International V AT Monitor, IBFD. 2020.

https://research.ibfd.org/\#/doc?url=/collections/ivm/html/ivm 202003 e2 3.h $\underline{\mathrm{tml}}$

[19] PrätZler, Robert C.: Split Payments in VAT Systems - Is This the Future? International VAT Monitor, IBFD, 2018. április https://www.ibfd.org/sites/ibfd.org/files/content/marketing/Journal Previews/I VM/International-VAT-Monitor-Mar2018.html

[20] Technologies for Better Tax Administration A Practical Guide for Revenue Bodies. OECD Publishing, Paris, 2016. https://doi.org/10.1787/9789264256439-en

[21] UChmanska, Urszula: Split Opinions about the Split-Payment Mechanism? A Discussion of the Polish Example. International VAT Monitor, IBFD, 2019. https://research.ibfd.org/collections/ivm/printversion/pdf/ivm 201904 pl 1.pd $\underline{f}$

[22] $\operatorname{COM(2018)~} 812$ final Javaslat a Tanács 2006/112/EK irányelvnek a pénzforgalmi szolgáltatók számára egyes kötelezettségek bevezetése tekintetében történő módosításáról https://ec.europa.eu/transparency/regdoc/rep/1/2018/HU/COM2018-812-F1-HU-MAIN-PART-1.PDF 
[23] A TANÁCS 2020. február 18-i (EU) 2020/283 Rendelete a 904/2010/EU rendeletnek a héacsalás elleni küzdelem érdekében folytatott közigazgatási együttmûködés megerôsítésére irányuló intézkedések tekintetében történő módosításáról.

[24] EY: Smart Taxation Policy Paper. https://www.ey.com/hu hu/tax/erositse-megceget-okos-adozassal

[25] Smart taxation for navigating tax rules and planning for growth young entrepreneurs. https://www.citizen-entrepreneurs.com/wp-content/uploads/2018/10/SmartTaxation-Policy-Paper-EY-G20YEA.pdf

[26] Maintaining healthy public finances. Smart taxation. https://ec.europa.eu/info/business-economy-euro/growth-andinvestment/structural-reforms/public-finances-and-taxation en\#smart-taxation

[27] Levi, Stuart D. - LipTON, Alex B.: An Introduction to Smart Contracts and Their Potential and Inherent Limitations. Harvard Law Forum on Corporate Governance. 26.05.2018. https://corpgov.law.harvard.edu/2018/05/26/an-introduction-tosmart-contracts-and-their-potential-and-inherent-limitations/ (Letöltve 2021.01.13.)

[28] Hometax World-Class Electronic Tax Administration Service. National Tax Service, Republic of Korea, 2016. https://www.mois.go.kr/cmm/fms/FileDown.do?atchFileId=FILE 00070312AU

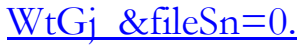

[29] File:Environmental tax revenue by type and total environmental taxes as share of TSC and GDP, EU-27, 2002-2019 (million EUR, \%).png - Statistics Explained (europa.eu)

[30] 2020-International-Tax-Competitiveness-Index.pdf (taxfoundation.org)

[31] Statement on the data breach in the National Revenue Agency of Bulgaria http://www.oecd.org/tax/transparency/documents/statement-on-the-data-breachin-the-national-revenue-agency-of-bulgaria.htm

[32] AsQuiTH, Richard: Italy SdI VAT e-invoicing raises €4bn https://www.avalara.com/vatlive/en/vat-news/italy-sdi-vat-e-invoicing-raises-$\underline{4 b n . h t m l}$

\section{Lektor}

Halász Zsolt Dr., PhD., tanszékvezető egyetemi docens,

Pázmány Péter Katolikus Egyetem Jog- és Államtudományi Kar,

Pénzügyi Jogi Tanszék,

halaszzs@yahoo.de 